EXEMPLARIa Classica

Journal of Classical Philology

19, 2015, pp. 131-154

ISSN 1699-3225

\title{
APULEIUS AND THE CODEX REGINENSIS
}

\author{
Justin Anthony STOVER \\ All Souls College, University of Oxford \\ justin.stover@all-souls.ox.ac.uk
}

SuMMARY

This article explores the place of Bibliotheca Apostolica Vaticana, Reginensis latinus 1572 in the manuscript tradition of Apuleius' philosophica. I show that its text is independent of those of the two major families, $\alpha$ and $\delta$, and that it represents a third branch of the stemma.

KEYWORDS

Apuleius, stemmatics, textual criticism.

\section{RESUMEN}

Este artículo explora el lugar del códice $B i$ blioteca Apostolica Vaticana, Reginensis latinus 1572 en la tradición manuscrita de las obras filosóficas de Apuleyo. Muestro que su texto es independiente de las dos familias principales, $\alpha$ y $\delta$, y que representa una tercera rama de la stemma.

Palabras Clave

Apuleyo, stemmática, crítica textual.

Fecha de recepción: 18/11/2014

Fecha de aceptación y versión final: 1/07/2015

The lineaments of the orthodox account of the descent of Apuleius' philosophica were traced over century ago by Paul Thomas. ${ }^{1}$ There are two

I would like to thank Tom Keeline and Richard Tarrant for looking over drafts of this study and providing comments; Christopher Parrott for discussing a number of points of detail with me; and the above all the anonymous referees of this journal who gave such thorough comments on the article. The final product would have been much worse without them.

${ }^{1}$ P. Thomas, "Étude sur la tradition manuscrite des oeuvres philosophiques d'Apulée", Bull. Acad. Royale de Belgique, Classe des Lettres, Brussels 1907, 103-47; cf. L. D. Reynolds, "Apuleius. Opera philosophica", Texts and Transmission: A Survey of the Latin Classics, Oxford 1983, 16-8. On Apuleius' philosophica in general, see now R. Fletcher, Apuleius' Platonism: The Impersonation of Philosophy, Cambridge 2014; and on his medieval and Renaissance reception, see. J. Gaisser, The Fortunes of Apuleius and the Golden Ass: A Study in Transmission and Reception, Princeton 2008; as well as her article "How Apuleius Survived: The African Connection", Apuleius and Africa, New York 2014, 52-65. B is available for consultation online through the Europeana Regia project. 
branches, now called $\alpha$ and $\delta$; $\alpha$ is the more reliable of the two, and the best and earliest representative of $\alpha$ is B (Brussels, Bibliotheque royale MS 10054$56) . \delta$ is somewhat younger than $\alpha$; its earliest representative, $N$ (Leiden, Voss. lat. Q. 10), appears around the beginning of the eleventh century. This is the basis on which Thomas produced his Teubner of 1908 (though not using N), J. Beaujeu his Budé of 1973, and finally C. Moreschini the completely revised Teubner of 1991. As Moreschini was working on his edition for the Stuttgart side of the Cold War split in the house of B. G. Teubner, Frank Regen was working on an edition of the philosophica for the Leipzig side. ${ }^{2}$ After the wall fell, and the two branches were once again reunited, it was Moreschini's edition that Teubner chose to publish. Regen, however, along with Raymond Klibansky, did publish some of his research in 1993 in the form of a (nearly) comprehensive catalogue of the manuscripts of the philosophica with a substantial appendix on their relationships. ${ }^{3}$ Regen and Klibansky harshly criticized Moreschini's edition, particularly for his dismissal of a group of thirteenth-century and later manuscripts, foremost among them R, Bibliotheca Apostolica Vaticana, Reg. lat. 1572, as a docta recensio. And so to this day, the question remains open: is $\mathrm{R}$ an independent witness to the archetype or not? Given the current lull in editing the philosophica, as we await the promised Oxford text of the corpus being prepared by Giuseppina Magnaldi, it seems a good idea to try to resolve this crux between a bipartite and tripartite stemma. ${ }^{4}$

\section{The Tradition of the Philosophica}

\subsection{The manuscripts}

The standard stemma of the tradition is as follows (I present the one from Texts and Transmission, slightly modified):

${ }^{2}$ I am grateful to Hans Bernsdorff for supplying me with details about Regen's edition.

${ }^{3}$ R. Klibansky and F. Regen, Frank Regen, Die Handschriften der philosophischen Werke des Apuleius. Ein Beitrag zur Überlieferungsgeschichte, Göttingen 1993; hereafter, this catalogue will be cited as Klibansky/Regen. The appendix is found on 158-68. Much of the evidence I present here can also be found there; the evidence however occasionally rests on faulty readings, uses a novel system of sigla, and lacks any substantial analysis. Thus many the examples I use below can be found there, but I have checked the readings in $\mathrm{R}$ and $\mathrm{B}$ from the manuscripts, and developed my evidence solely from the collation of the manuscripts and from Moreschini's apparatus.

${ }^{4}$ To judge from the work Magnaldi has published thus far, her edition will represent a substantial improvement: "Antiche glosse e correzioni nel De deo Socratis di Apuleio", RFIC 139, 2011, 101-17; "Antiche note di lettura in Apul. Plat. 193, 223, 242, 248, 253, 256 e Socr. 120", RFIC 139, 2011, 394-412; "Tracce di antiche omissioni-integrazioni nel De Platone di Apuleio", Vestigia notitiai. Scritti in memoria di Michelangelo Giusta, Alessandria 2012, 351-65; "Usus di copisti ed emendatio nel De Platone di Apuleio, MD 68, 2012, 153-72; "Antiche tracce di 'apparato' nel testo tràdito di Apuleio filosofo", Lexis 30, 2012, 478-92; "Il De Platone di Apuleio: lezioni tràdite e congetture", BStudLat 42, 2012, 570-7.

${ }^{5}$ Reynolds, “Apuleius”, 17. 


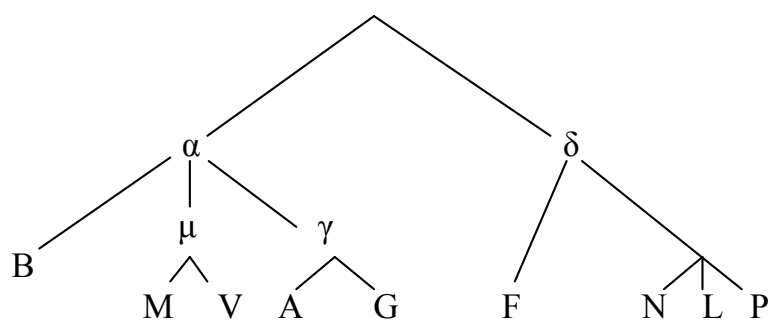

B Brussels, Bibliothèque royale MS 10054-56 (Klibansky/Regen, no. 8), with two principal correctors $\mathrm{B}^{2}$ and $\mathrm{B}^{3}$, both much later than the main text

M Munich, Bayerische Staatsbibliothek Clm 621(Klibansky/Regen, no. 51)

V Vatican City, BAV, Vat. Lat. 3385 (Klibansky/Regen, no. 100)

A Paris, Bibliothèque nationale, Ms lat. 8624 (Klibansky/Regen, no. 67)

G Wolfenbüttel, Herzog August Bibliothek, Gud. lat.168 (Klibansky/ Regen, no. 108)

F Florence, Biblioteca laurenziana, San Marco 284 (Klibansky/Regen, no. 27)

N Leiden, Universiteitsbibliotheek, Voss. Lat. Q. 10 (Klibansky/Regen, no. 42)

L Florence, Biblioteca laurenziana, plut. 76.36 (Klibansky/Regen, no. 23)

$\mathrm{P}$ Paris, Bibliothèque nationale, Ms lat. 6634 (Klibansky/Regen, no. 63)

Other manuscripts:

R Vatican City, BAV, Reg. lat. 1572 (Klibansky/Regen, no. 90)

C Cambridge, Corpus Christi College, MS 71 (Klibansky/Regen, no. 10)

H London, British Library, MS Harley 3969 (Klibansky/Regen, no. 46)

O Vatican City, BAV, Ottob. lat. 1935 (Klibansky/Regen, no. 87) 
$\mathrm{Pb}$ Paris, Bibliothèque nationale, Ms lat. 6286 (Klibansky/Regen, no. 62)

T London, British Library Ms Add. 11983 (Klibansky/Regen, no. 44)

U Vatican City, BAV, Urb. Lat. 1141 (Klibansky/Regen, no. 92)

In addition to the manuscripts, we have indirect testimonia from Augustine and John of Salisbury: the former had a text undoubtedly superior than that of our archetype, the latter is a witness to a useful but contaminated strain of twelfth-century manuscripts, related probably to $\mathrm{C}$ and $\mathrm{H}^{6}{ }^{6}$

\subsection{Non- $\alpha \delta$ readings in the Teubner text}

The state of the text as transmitted is nothing short of atrocious. I can think of no Latin prose text with a comparable medieval circulation which was transmitted in so appalling a condition. Unreliable traditions encourage eclectic editorial practice, and Moreschini's text offers no exception. Well north of a hundred readings from manuscripts outside of the two main traditions are adopted by Moreschini. I have selected some noteworthy examples taken from the whole corpus (here, as elsewhere, where the contaminati are not reported, they should be assumed to follow $\alpha \delta)$ :

Socr. prol. 3 p. 107 extimas R] exoptimas BNP om. $\mu$ exoptimis cett.

Socr. prol. 4 p. 108 parvam RAFP ${ }^{2}$ parum $\alpha \delta$

Socr. 1 p. 117 largius R] longius $\alpha \delta$

Socr. 3 p. 124 munia $\mathrm{B}^{2} \mathrm{R}$ ] mutua $\mathrm{B}$ cett. (mutuam M)

Socr. 4 p. $128 \quad$ ceteri B ${ }^{2}$ AGRO] celeri $\alpha \delta$

Socr. 7 p. $136 \quad$ conruget $\left.\mathrm{RH}^{2}\right]$ conroget $\alpha \delta$

Socr. 8 p. 143

Ascl. 10

Ascl. 37

Plat. 2.2 p. 183 ventis $\left.R^{2} V^{2} P^{2} C H\right]$ venis BVP cett. hominis R] omnis $\alpha \delta$ ex utraque natura $\mathrm{RGL}^{2}$ Augustine] extraque naturam BMFNPL extraque natura $\mathrm{U}$ ex utraque naturam $\mathrm{V}$

Plat. 1.2 p. 184 acre RC John of Salisbury] aere $\alpha \delta$ lucta R] luctu A luctata $\alpha \delta$ se utilem RA] sentilem $\alpha \delta$ finxit RFC] fixit $\alpha \delta$

Plat.1.7 p.194 multimoda B $\left.{ }^{2} \mathrm{R}\right]$ multi B multimoda multi $\alpha \delta$

Plat. 2.1 p. 221

Plat. 2.5 p. 227 humana $\left.\mathrm{B}^{3} \mathrm{R}^{2} \mathrm{H}\right]$ humera $\alpha \delta$

Plat. 2.16 p. 243 domitas R] indomitas $\alpha \delta$ inexplebili $\mathrm{RH}$ ] inexplebilis $\alpha$ inexplicabilis $\delta$ inexplicabili $\mathrm{F}$

${ }^{6}$ See Beaujeu's introduction to his edition, $x x x v$ and xliv. 
mund. 7 p. 301

mund. 9 p. 308

mund. 27 p. 351 sinus $\mathrm{R}$ ] sinul $\mathrm{B}$ sinum $\mathrm{B}^{2}$ simul $\alpha \delta$

gelatus humor $\mathrm{FR}$ ] gelatu summo $\mathrm{B}^{3}$

gelat(a)e summa $\alpha \delta$

Some of these readings could well be the result of happy conjecture; nonetheless, taken in total, the correct manuscripts readings coming from outside $\alpha \delta$ are too numerous and in some cases too good to be the product of a docta (or even doctissima) recensio. Instead, they suggest irresistibly that there is at least a third source for the text outside of the $\alpha$ and $\delta$ traditions.

\section{$1.3 \varphi$ and $R$}

This tradition I will call $\varphi$, and as the collations above show, the most plausible candidate for consideration as a $\varphi$-manuscript is R. If we look at just the four lengthy omissions in the text of the De Platone, the independence of $\mathrm{R}$ from both $\alpha$ and $\delta$ is obvious:

Plat. 2.9 p. 233 coniungit nam ut illa medicinae $\mathrm{R} \delta$ ] om. $\alpha$

Plat. 2.10 p. 235 alia ceterorum pleraque et sui et aliorum, ut stultitia et eiusmodi vitia quae et sui causa vitanda sunt $\mathrm{RF} \alpha$ ] om. $\delta$

Plat. 2.20 p. 248 dici futurum quod et omnia $\mathrm{R} \delta$ ] om. $\alpha$

Plat. 2.21 p. 250 pecuniae sed praesentiam (praesentia F) R $\delta$ ] om. $\alpha$

The fuller text, however, offers no guarantee against contamination; and as one can see above, a $\delta$ manuscript, $\mathrm{F}$, to which I will return below, also offers a complete text. Now we can look at some of R's correct readings, some of which are far better than could be the result of medieval conjecture, such as:

Socr. prol. 3 p. 107 extimas R] exoptimas BNP om. $\mu$ exoptimis cett mund. 7 p. $301 \quad$ sinus $\mathrm{R}$ ] sinul $\mathrm{B}$ sinum $\mathrm{B}^{2}$ simul $\alpha \delta$

Since $\varphi$ readings like these are both certainly correct and beyond conjecture, did they enter the tradition through the archetype or from elsewhere? In other words, are these stemmatic or extrastemmatic readings? As Timpanaro has shown, in some traditions it is possible that a second line of transmission survived into the Middle Ages, where it contaminated other manuscripts but left no progeny of its own. ${ }^{7}$ In the corpus of the philosophica, there are some examples of extrastemmatic contamination from the De civitate Dei of Augustine, which quotes parts of the corpus extensively often in versions 179.

${ }^{7}$ S. Timpanaro, The Genesis of Lachmann's Method, trans. G. Most, Chicago 2005, esp. 
far superior to that transmitted by most of the extant manuscripts (see, for example, Socr. 12 p. 146, discussed at 2.5.a below). The way to answer this question for R's readings is to determine whether one can demonstrate that $\mathrm{R}, \alpha$, and $\delta$ all descend separately from a single archetype. The best evidence to demonstrate this comes from the cases where there are two or three different readings which could only represent different ways of reading a single manuscript.

\section{THE INDEPENDENCE OF $\mathrm{R}$}

\subsection{Incorporated corrections}

We shall first examine cases of incorporated glosses or corrections.

a. Ascl. 1 scribam nomine $\mathrm{B} \mu$ ] scribam nomini $\mathrm{R}$ scribo nomini $\mathrm{F}$ scriba bo.ni $\mathrm{N}$ scribam nomine boni GPLT scribam boni nomine $\mathrm{U}$

This is a delightfully limpid case of the process of intrusion. The boni we find across the $\delta$ tradition is factitious, a phantom reading produced from the combination of two separate glosses in the archetype. The archetype almost certainly read:

\section{scribamnomine}

The $\alpha$ family transmitted the actual text of the archetype, while $\mathrm{R}$ adopted one of its corrections but not the other. The $\delta$ manuscripts contain various combinations of the gloss and the main text, most of them combining the two separate glosses into a new word boni.

\section{b. $\quad$ Socr. 24 p.177 nec $\mathrm{B} \mu$ haec $\mathrm{V}^{2} \mathrm{AFRO}$ hec nec $\mathrm{G} \delta$}

Whatever this word may be, it is deleted by most editors. Nonetheless, across the tradition, one can still see two different readings, nec and haec, the $\alpha$ family with the former, $\mathrm{R}$ and some of the contaminati with the latter The $\delta$ family, by contrast, contains both, suggesting an archety pal reading of:

haec
nec or haec

An example similar to this may be found later:

c. Ascl. 9 non fecit $\mathrm{B} \mu \mathrm{G}]$ confecit $\delta$ non confecit FR

\subsection{Errors of word division}

a. mund. 17 p. 326 ut Liparae, ut Aetna, ut Vesuvius edd. 
Moreschini's apparatus is impossibly confused, as it divides this phrase into three. In order to untangle the manuscript readings, let us start with his three entries in entirety:

ut Liparae BVR Tho. Beau. : ut Lipara FNPL ${ }^{2}$ (ex lippara) U, ut Lipara Iunt., ut Liparis Flor.

ut Aetna Iunt. Tho. Beau. : uutahetna B, euuta etna FNLPU uita et V, uta et R, et Aetna Gold.

ut Vesuvius Iunt. : nautuae (nautae V) subius BV, ut vesubius FNPLU, nentue subius $R$, vesubius $\mathrm{V}$

The situation is not quite so bad as this apparatus would make it seem, when the real problem with word division is taken into account. The intrusive $e$ before uut in $\delta$ is really just the missing $e$ from Lipara, while the strange $n e$ in $\mathrm{R}$ before $n t v e$ (which is just a simple minuscule error for utve) is really just the missing syllable from the end of Aetna. This situation is made worse by transcription error: $B$ in fact reads:

utliparaeuutaetnautuaesubius

which has been divided as:

ut|liparaeuuta|et|nautuae|subius

Moreschini's reading reports the $n a$ twice. So in reality $\alpha$ only has two mistakes (when we discount word division), a superfluous gemination of the $u$ in the second $u t$, and the hypercorrected Vaesubius; $\delta$ has only the first of these, and a word division of ut lipara euuta etna ut vesubius. R reads: ut lipareuta et nentue subius. One must feel some twinge of pity for the poor scribes tasked with trying to make sense of this cascade of mountain names from an undoubtedly corrupt exemplar. Ultimately, the only problem in the exemplar was the iterated $u$, which could have been a misguided correction attempting to change the et into ut. Regardless, the actually interesting fact here is that we have two different models of word division:

ut liparaeuuta et nautuae subius

ut lipara euuta etna ut vesubius

ut lipareuta et neutue subius

The affiliations here clearly indicate a tripartite division:

lipar(a)e BR] lipara e $\delta$

ut $\mathrm{R}$ ] uut $\mathrm{B} \delta$ 
a etna $\delta]$ a et na $\mathrm{B}$ a et ne $\mathrm{R}$

ut vesubius $\delta$ ] utuae subius $B$ utue subius $R$

Since all three branches transmit nonsense, one cannot fall back on the idea of $\mathrm{R}$ as a docta recensio, unlike $\mathrm{V}$, for example, which at least attempts to turn the sequence of letters into recognizably Latin words ut Liparae vita et nautae subius. One might also note that R's Aetne is an accepted spelling, more closely modeled on the Greek. ${ }^{8}$

A similar case can be found later in the same passage:

b. mund. 17 p. 327 hiatu reseratum $\delta$ ] hiatur esse ratum $\mathrm{B}$, hiacure seratum $\mathrm{R}$, hiatus esse raptum $\mathrm{V}$

The correct reading is preserved by $\delta$, while the faults in both $\mathrm{R}$ and $\alpha$ arise out of faulty word-division. The latter read a passive verb hiatur and ratum at the end, which left an awkward ese in the middle, read naturally as esse. The former saw a future participle hiatur(a)e (the alternation between $c$ and $t$ is trivial here) and then seratum, which is at least close to a genuine Latin word. The only way these three variants could exist is by common descent from a single exemplar in scriptura continua, reading:

\section{hiatureseratum}

Once again, one cannot resort to the theory of the docta recensio, since neither $\alpha$ nor $\mathrm{R}$ makes sense in the sentence.

c. $\quad$ Socr. 7 p. 137 rapere sed reddere $\mathrm{R}^{2} \alpha$ ] reddere $\delta$ red rapere sed reddere $\mathrm{R}$

$\mathrm{R}$ has an obvious double reading here: the phrase begins in the codex with an unmistakable red followed by the phrase as it stands in $\alpha$. The corrector then deleted red with puncti under the $r$ and $d$. A possible explanation for this bizarre reading is that the archetype from which $\mathrm{R}$ is ultimately derived had both readings, something along the lines of:

\footnotetext{
apicemreddere

d. mund. 9 p. 308 gelatus umor rigore frigoris inhorrescit $e d d$.
}

${ }^{8}$ This is not the only instance where the text in R offers a stricter Greek orthography; see also Plat. 1.1 p. 181 delum B $\delta$ ] delon R 
Moreschini's apparatus is misleading once again; he divides this into three separate entries, which obscures the fact that this is simple case of corruption from scriptura continua. Combining the three entries we get the following:

gelatu summo rigore frigoris inhorrescit $\mathrm{B}$ corr. $<$ sub rasura > inhorrescit $B$ gelatae summo rigore inhorrescunt $\delta$ gelatus humor rigore frigoris inhorrescit $\mathrm{R}$

The reason why the obviously correct gelatus umor became gelatae summo was because of the misanalysis of the " $\mathrm{s}$ " and the iteration of the " $\mathrm{r}$ ". The archetype likely read:

\section{gelatusumorrigorefrigorisinhorrescit}

That is the correct reading, and that is what $\mathrm{R}$ transmits, ignoring the trivial orthographical variant humor. At some point, the archetype was badly corrected to misdivide gelatus umor rigore as gelatu sumo rrigore and then delete the iterated " $\mathrm{r}$ ".

Moreschini does not tell us that the whole phrase here from gelatu to frigoris was scraped off in $\mathrm{B}$, to be replaced by gelatu|sumolrigorelfrigoris in a later hand. (The reading gelatae he attributes to B is nowhere to be found here; presumably his "gelatu $\mathrm{B}^{3 \text { " }}$ refers to the galatu (sic) added in the margin by a much later hand.) The original reading is thoroughly erased: all that can be picked out are the clubbed ascenders of the original "l" and the final "s". This second mark is important, since it points to an original frigoris which is precisely the word omitted in the $\delta$ manuscripts. Inhorrescit does remain in the original text of $\mathrm{B}$, which gives us in all an almost legible reading, although it is not clear what might be the subject of the verb.

The scribe of $\delta$ was evidently not pleased with this, and, mistakenly supposing symmetry between this clause and the one proceeding it which begins fractae et discissae, conjectured gelatae, probably because, like the scribe of $\mathrm{B}$, he assumed that the $s$ went with the following word. He then thought he caught a doublet in rigore frigoris. Finally, he also fixed the verb, giving us the comprehensible reading gelatae summo rigore inhorrescunt.

This example is yet another piece of evidence that R's ancestor was copied directly from the archetype. It also suggests one of two possibilities, either that the scribe of $\varphi$ ignored the work of the corrector altogether, or else that the archety pe was corrected here after $\varphi$ was copied.

e. $\quad$ mund. 26 p. 348

omne Asiaticum edd.] omne atticum $\delta$ omnes atticum $\mathrm{B}$ omnes iaticum $\mathrm{R}$ 
Here we are dealing with another problem of word division, a fact obscured by Moreschini's division of this into two entries in apparatus. Assuming scriptura continua again, the correct reading is:

omneasiaticum

The first "a" has left no mark in the extant tradition, which allows us to assume that the archetype had the erroneous reading:

omnesiaticum

This is the reading we find in $\mathrm{R}$, with the word division falling after the "s" making a comprehensible omnes followed by the nonsense iaticum (incidentally, another piece of evidence that $\mathrm{R}$ cannot be a docta recensio). $\mathrm{B}$ divided the sequence the same way, but emended the nonsense to a real geographical adjective atticum which at least is capable of being read even if flatly wrong. (It is amusing to reflect on how 'the Hellespont forms the western boundary of every Attic kingdom'.) The $\delta$ hyparchetype, however, recognized the need for a neuter adjective, and simply changed omnes to omne. The confluence of atticum in both $\alpha$ and $\delta$ should lead us to suspect that a corrector had supplied it in the archetype as a plausible replacement for (s)iaticum.

\subsection{Bipartitions}

The cases thus far have tripartite divisions, but important evidence can be gleaned from bipartite divisions as well:

a. Ascl. 30

nec stabit aliquando nec corrumpetur sempiternitate $e d d$.] nec stabili quando nec corrumpetur sempiternitate $\mathrm{B} \mu \gamma \delta$ non corrumpetur aliquando stabili sempiternitate FR Rom.

All the manuscripts transmit nonsense, and in fact we find the same nonsense in both the $\alpha$ and $\delta$ traditions. Nonetheless, what we have here is an error of word division in the archetype from an original necstab; aliquando. Quite sensibly a corrector changed the seeming nonsense stabali quando into stabili quando. $\mathrm{R}$, along with $\mathrm{F}$, besides the characteristic disturbance of the word order, preserves both readings, thereby doubling the (a)li. Hence the archetype could have read:

stabaliquando 
Under this theory, he archetypes of $\alpha$ and $\delta$ read only the incorrect correction, while $\varphi$ read both.

b. Ascl. 24 vate somniis $\mathrm{T}^{2}$ August.] vatas omnes $\mathrm{B}$ vittas omnis $\mathrm{B}^{2}$ vatas omnis $\mu$ vates omnis somniis $\mathrm{R}$ vates ominis $\gamma$ vates omnis $\delta$

The archetype of $\alpha$ read vatas omnis while that of $\delta$ read vates omnis. But $\mathrm{R}$ transmits both the correct somniis as well the mistaken $s$ on vates and the extra somniis. This double reading indicates that the archetype likely read:

\section{vatesomnis}

The two main families read only the main text, and not the correction, whereas $\varphi$ read both.

$$
\begin{array}{ll}
\text { c. Ascl. } 22 \quad \text { compositum est . . . constitutum esse } \mathrm{B} \mu \gamma \delta] \\
\\
\text { compositum . . constitutum est esse } \mathrm{RF} \\
\text { compositum et . . constitutum esse } \mathrm{B}^{2}
\end{array}
$$

Moreschini erroneously attributes to B the reading compositum est. . . constitutum est esse; in reality, the main hand of B presents the same reading as all the other manuscript besides $\mathrm{R}$ and $\mathrm{F}$. Both readings are plausible; Moreschini and Beaujeu print the majority reading, while Thomas, with greater acumen in my view, printed the reading he knew only from $\mathrm{F}$. The actual textual (as opposed to semantic) distinction between the two readings is the placement of est. The difference between the two possibilities is about the space of thirty characters, depending on abbreviation: sic compositum (est) per voluntatem dei hominem constitutum (est). We have evidence from both $\mathrm{B}$ and $\mathrm{R}$ that the archetype had lines of about thirty characters in length: hence it seems very likely that here we are seeing a misplaced addition.

$$
\begin{aligned}
& \text { divinaatquemortalietsiccōpositū } \\
& \text { pervoluntatēēîhominēcōstitutū }
\end{aligned}
$$

\subsection{Independent errors of word division in $R$}

Another category of bipartite divisions are where $\mathrm{R}$ presents simple mistakes arising out of faulty word division. While easy to spot and correct, these errors are very telling: they confirm that $\mathrm{R}$ descends from an archetype written in scriptura continua independent of $\alpha$ and $\delta$ (I do not note separately for these instances the fact that $\mathrm{B}$ is written in continua). 
Socr. 3 p. 125

Plat. 2.2 p. 222

Plat. 2.4, p. 225

Plat. 2.7 p. 228

mund. 5 p. 298

mund. 13 p. 319

mund. 27 p. 370

mund. 35 p. 367 ac iam edd.] faciam $\mathrm{R}$ fac iam cett.

nec pari aut] nec pariant $R$ et putatur] eputatur $\mathrm{R}$

debet servit aliis] diebus servitalis $\mathrm{R}$ deb; servit aliis $\mathrm{R}^{2}$

esse et] esset $\mathrm{R}$

peloponnesos $\mathrm{V}^{2}$ ] pelos pennesos $R$ pelopennesos $\mathrm{V}$ cett.

Vulturno reflat] vulturnore flat $\mathrm{R}$

illi Koóvov edd.] illicro non $\mathrm{R}$ illi cronon cett. obitis $\mathrm{C}]$ ab his $\mathrm{B}^{2} \mathrm{U}$ ob hiis $\mathrm{R}$ obiis cett.

\subsection{Sole transmission}

The most compelling - indeed, the conclusive - evidence for R's independence would be authentic material preserved in $\mathrm{R}$ which is not found in the other manuscripts. If, as I have argued, the stemma is tripartite, such cases ought to be very rare, since the only way it could occur is through independent omission or else by means of interlinear or marginal supplement in the archetype which only $\mathrm{R}$ copied. Nonetheless, there are three instances in the De deo Socratis and one in the De Platone which could represent genuine material preserved only in $\mathrm{R}$.

a. Socr. 6 p. 133 inter terricolas caelicolasque $\left.\mathrm{B}^{2} \mathrm{H}\right]$ inter homines caelicolasque RO inter caelicolasque cett.

Both $\alpha$ and $\delta$ evidently omitted the word following inter, which leaves two possibilities, that it was omitted in the archetype (which would make both readings medieval conjectures) or that it was transmitted in the archetype in some fashion and independently omitted in both $\alpha$ and $\delta$, but retained in $\varphi$. I fail to see any plausible editorial justification for presuming that either $\mathrm{B}^{2}$ or $\mathrm{H}$ could preserve authentic material. $\mathrm{H}$, as we have seen, is a learned recension, itself deriving ultimately from $\mathrm{N}$. As a corrector, $\mathrm{B}^{2}$ is undoubtedly clever, but too clever by half - for example, a little later, at Socr. 12 p. 146, he replaces a whole nonsense phrase in the main hand, et vere illos secundum, with the sensible and undoubtedly correct hos prosperare et evehere contra illos. All the other codices transmit the first version, while the second comes verbatim from Augustine's quotation of the line in the De civitate (9.3). There is no reason to suppose that the genuine phrase was found in the archetype - just as $\mathrm{H}$ used Cicero, so $\mathrm{B}^{2}$ used Augustine to restore the corrupt phrase. These suspicions are confirmed by Pasquale Arfé's spectacular unmasking of the corrector's identity: Giovanni Andrea Bussi, the secretary of Nicolas of Cusa and the editor of Apuleius the editio princeps of 
Apuleius. ${ }^{9}$ The fact that terricolas can be attributed to two individuals, Bussi and William of Malmesbury, known for their clever and adventurous textual interventions, should make us suspicious of the terricolas. Indeed Bussi does not even print terricolas in his edition, opting instead for mortales, confirming its status as his own (ultimately rejected) conjecture. ${ }^{10}$

And indeed terricolas stands condemned for other reasons: the word does not appear until the sixth century at least, in the Regula Augustini, a grammatical text, and the first instances of it are only found in lists of -cola words. Nonappearance of a word elsewhere does not rule out the possibility that Apuleius used it, but the fact that this word becomes moderately common in the Middle Ages should make us highly suspicious that it is a medieval supplement. Indeed, it is such an easy guess in parallel to caelicolas that Bussi and William probably came up with it independently.

The proper counterpart to caelicolae are homines: see, for example, Catullus 30.4, nec facta impia fallacum hominum caelicolis placent, Ausonius, ecl. 19.2, caelicolum duo sunt et duo festa hominum, and indeed Apuleius himself (implicitly) in a passage discussing the same theme as this one. ${ }^{11}$ Homines of course is hardly a flashy conjecture, and even a somewhat dull copyist could have inserted it. But $\mathrm{R}$ (and it is beyond doubt that $\mathrm{O}$ got the reading from $\mathrm{R}$ ) does not tend to fix up the text at all, which on balance suggests that homines is genuine and transmitted from the archetype. It may well have been an insertion by the corrector ignored independently by $\alpha$ and $\delta$.

b. Socr. 8, p. 137 terrarum <aquarum> flammarum Merc.] terrarum quaedam flammarum $\mathrm{R}$ terrarum flammarum cett.

The Paris 1625 edition of Josiah le Mercier (the father-in-law of Salmasius) was the first to provide the correct restoration, animalia terrarum aquarum flammarum. Where all the other codices have a lacuna, $\mathrm{R}$ has quaedam unreported by Moreschini. One could object that this quaedam is a dittography - $\mathrm{R}$ transmits a quaedam a few words earlier in the same words, where the other manuscripts read quae. Nonetheless, it beggars belief that $\mathrm{R}$ independently inserted a word precisely where a word had dropped out of the paradosis, and that R's new word would just happen to

\footnotetext{
${ }^{9}$ Pasquale Arfé, "The Annotations of Nicolaus Cusanus and Giovanni Andrea Bussi On the Asclepius", JWI 62, 1999, 29-59.

${ }^{10}$ The anonymous referee of this journal drew my attention to the reading in the editio princeps here.

${ }^{11}$ Plat. 1.11 p. 204-5: Deorum trinas nuncupat species, quarum est prima unus et solus summus ille, ultramundanus, incorporeus, quem patrem et architectum huius divini orbis superius ostendimus; aliud genus est, quale astra habent cetera que numina, quos caelicolas nominamus; tertium habent, quos medioximos Romani veteres appellant, quod [est] sui ratione, sed et loco et potestate diis summis sint minores, natura hominum profecto maiores.
} 
have a similar visual and phonetic shape to the omitted word, quaedam to aquarum. Rather, it was dittography that facilitated the replacement of aquarum with quaedam, particularly if earlier corruption had already rendered aquaram deformed, with omission, for example, of the initial "a" (a feature we have already seen above in 2.1.e).

c. Socr. 10 p. 143 nonne audis] nonne vides nonne audis $\mathrm{R}$

This is another $\mathrm{R}$ reading not reported by Moreschini. All the other manuscripts transmit the perfectly sensible nonne audis quid super tonitru Lucretius facundissime disserat introducing a quotation from the DRN (6.96-8). $\mathrm{R}$ begins this phrase with nonne vides nonne audis, a reading one might be awfully tempted to characterize as a doublet. But this is a genuine Lucretian phrase (6.813), nonne vides audisve, from the same book as the following quotation, though much later. I think that there is some reason to accept it is genuine, but genuine or not, I do not think one can chalk up this reminiscence of Lucretius directly preceding a quotation of Lucretius to merely mechanical error. And if so, then nonne vides is not a medieval accretion (Lucretius was scarcely read), but an ancient one, omitted in $\alpha$ and $\delta$ by a simple two word saut du même au même.

d. Plat.1.2 p.183 pueri eius] puericie eius $\mathrm{R}$ acre RC] aere cett. in percipiendo edd.] imperciendo $\mathrm{R}$ in perciendo cett. primitias ... imbutas refert] post refert add. maioribus annis politicas $\mathrm{R}$

This sentence, describing Plato's education and an important fragment of Speusippus, was evidently already deformed in the exemplar (pp. 18384 Moreschini): Nam Speusippus domesticis documentis instructus et pueri eius acre in percipiendo ingenium et admirandae verecundiae indolem laudat et pubescentis primitias labore atque amore studendi imbutas refert et in viro harum incrementa virtutum et ceterarum convenisse testatur. Only $\mathrm{R}$ and $\mathrm{C}$ preserve the correct reading acre, and no manuscript transmits the undoubtedly correct percipiendo. $\mathrm{R}$ offers two variants unreported by Moreschini. The first is pueritiae for pueri, which offers little ground for choosing one way or the other. More importantly, $\mathrm{R}$ adds the words maioribus annis politicas. As it stands, this supplement is nonsense; nonetheless, it retains something of the authentic flavour of biography with the words maioribus annis. ${ }^{12}$ It is exceedingly doubtful that

${ }^{12}$ See, for example, Consult. Zacch 1.12.1: quid momenti fuit infantem in cunis uagisse, deinde in puerili ignorantia remoratum, aut lubricum adolescentiae tempus annis non transisse maioribus...? The phrase in annis maioribus is also found in legal contexts, cf. Cod. Theod. 4.8.6. 
a copyist could have composed so apropos a supplement, particularly since the context requires none. Further, it cannot possibly be R's own supplement since it is itself corrupt: politicas is a deformation of an original politas. Any mid-thirteenth-century scribe who came across the word politas in a work on Plato may well have automatically written politicas or something similar. With imbutas ... politas, compare the expression found a little later (1.2 p. 188): cum principes harum familiarum impolitas sententias et inchoatas auditoribus tradidissent, eas hic cum ratione limando tum ad orationis augustae honestissimam speciem induendo perfectas atque etiam admirabiles fecit. For the moral sense of politus, compare Varro, rust. 1.2.10: uirum omnibus uirtutibus politum. The fact that this supplement provides a characteristic Apuleian clause-ending (planus/ditrochee), unlike imbutas refert, confirms its authenticity. Hence, the restored passage should read:

Nam Speusippus domesticis documentis instructus [planus]

et pueri eius acre in percipiendo ingenium et admirandae verecundiae indolem laudat, [planus/cretic-trochee]

et pubescentis primitias labore atque amore studendi imbutas refert, maioribus annis politas, [planus/ditrochee]

et in viro harum incrementa virtutum et ceterarum convenisse testatur.

[planus/cretic-trochee]

For Speusippus, instructed by the family records, both mentions his keen talent for perception as a boy and his natural endowment of admirable modesty, and relates how his first-fruits as he entered youth were imbued with hard work and love of study, and then polished as he got older, and testifies that the increase of these and other virtues came together in him as a man. ${ }^{13}$

\subsection{Hard cases}

As argued above, the omissions strongly indicate that $\mathrm{R}$ cannot be placed into either of the two families, since it does not share the characteristic omissions of either, and neither of them share those of $\mathrm{R}$. There is, however, one exception:

a. Ascl. 30 remeat... agitatio $\delta]$ om. $\mathrm{R} \alpha$

The larger context is essential here: sed magis et ipsa immobilis aeternitas, in quam omnium temporum agitatio remeat et ex qua

${ }^{13}$ The translation is mine, but I profited from that by Fletcher, Apuleius's Platonism, 57. 
omnium temporum agitatio sumit exordium. The omission of half of this phrase was virtually inevitable at some point in the manuscript tradition: this is as typical a case of saut du même au même as can be conceived. Due to this unique circumstance, it is not entirely impossible, although still very unlikely, that $R$ and $\alpha$ independently omitted the same text. It is also possible, however, and much more likely, that the archetype itself contained the omission, which was subsequently supplied by the corrector. In light of all the other evidence, this reading does not give sufficient warrant to hold that $\mathrm{R}$ was even in part derived from $\alpha$.

In addition to this shared omission, there is also a doublet in both $\mathrm{R}$ and $\alpha$ :

b. Plat. 2.27 p. 261 post multitudo iterant flecti (pro deflecti) ... hominum multitudo $\mathrm{R} \alpha$

Obviously, $\mathrm{R}$ and $\alpha$ have to be very closely linked here, not only because they both contain this lengthy doublet of 22 words, but they also have the same error within the doublet, flecti for deflecti (both transmit deflecti, in agreement with $\delta$, in the first iteration of this phrase). Once again, this is a simple même au même doublet, but we cannot even entertain the possibility of independence. Rather than conclude that $\mathrm{R}$ is derived from $\alpha$, it seems more plausible to suggest that the iteration was itself contained in the archetype, and then excised as an easy correction by $\delta$. Intriguingly, these kinds of doublets are typical of $\mathrm{R}$, which has another not shared with the other manuscripts (and not reported by Moreschini):

c. mund. 18 p. 330 iamque albi quis lateribus proximaque queque iactantes et acutis angulis mobiles epiglote grece appellantur qui subliunt excucientes honera et recuperantes directis angulis mobiles epiglete gre appellantur sed qui subliunt excutientes honera et recuperantes directis angulis braste vocitantur $\mathrm{R}$

Just as in Plat. 2.27 p. 261 above, the doublet preserves two separate readings, here epiglote and epiglete, where $\alpha$ offers aepidetae (epidete VF) and $\delta$ expedite, where Apuleius wrote the hapax epiclintae.

These two passages offer the best contrary evidence to the theory defended here, yet neither of them singly nor both of them together actually offer conclusive proof, nor even a sufficient weight of evidence to outweigh all the indications pointing towards R's independence.

\subsection{A new ancient text in $R$}

I have made this case for the independence for $\mathrm{R}$ solely on the basis of the text of the standard works of philosophical corpus, because I am firmly 
convinced that there is sufficient evidence on purely textual grounds to perceive the independence of $\mathrm{R}$ from the other two traditions. Nonetheless, for the sake of completeness, I should point out that $\mathrm{R}$ uniquely preserves a hitherto unedited text directly following the explicit of the De mundo. This text, just under five thousand words in length, is a summary of fourteen of Plato's dialogues, and could not possibly have been written any time between the close of antiquity and the copying of $\mathrm{R}$ around 1250. There is extremely strong evidence - stylistic, lexical, intertextual, doctrinal, generic - which ties this text closely to the Apuleian corpus, and to the De Platone in particular. Elsewhere I argue that Apuleius is the author, and provide an editio princeps ${ }^{14}$ Here I will just point out that the quality of the text in $\mathrm{R}$ matches precisely what we would expect of a manuscript that contains unique material: a degree of textual independence which indicates that it was copied from a different exemplar than the other surviving copies. There is very strong evidence that this new text travelled with the Apuleian corpus as late as the seventh century; my theory is that it physically dropped out of the archetype after $\varphi$ was copied.

\section{Revisiting the Manuscript Tradition}

\section{$3.1 R$ and $\varphi$}

$\mathrm{Up}$ to this point, we have operated under the assumption that $\mathrm{R}$ is not $\varphi$. Fortunately, this too is capable of demonstration. Besides producing $\mathrm{R}, \varphi$ did manage to influence the main tradition through contamination of $\mathrm{F}$ and $\gamma$, the parent of A and G. First F:

Socr. prol. 3 p. 108 rotunditate FR] rotunda cett.

Socr. 22 p. 171 solus om. FR

Ascl. 8

dei ipsa FR] ipsa $\mathrm{B}^{2}$ de ipsa cett.

Ascl. 39

Plat. 1.7 p. 194

Plat. 2.19 p. 247 anne $\mathrm{B}^{2}$ ] ante (aut L aut ante $\mathrm{U}$ ) $\mathrm{B} \delta$ si FR

Plat. 2.21 p. 250

mund. 2 p. 292 et aquam et terram] aquam terram FR iisque $\mathrm{FR}$ ] isque $\mathrm{B}$ usque $\delta$ abstinentia FR] abstinentiam $\mathrm{B} \delta$

mund. 8 p. 306 sunt et FR] sunt ut $B \delta$

mund. 14 p. 321 obolitionem B $\delta$ ] abolitionem FR Beau. loquare FR] loquaere B locare $\delta$

${ }^{14}$ J. Stover, A New Work by Apuleius: The Lost Third Book of the De Platone, Oxford forthcoming 2015. The text was discovered by Raymond Klibansky; full bibliography can be found in Klibansky/Regen no. 90. On the authenticity of the work, see also J. Stover and M. Kestemont, "Reassessing the Apuleian Corpus: A Computational Approach to Authenticity,” CQ, forthcoming 2016; and J. Stover, Y. Winter, M. Koppel, and M. Kestemont, "Computational Authorship Verification Method Attributes New Work to Major 2nd Century African Author," Journal of the Association for Information Science and Technology, forthcoming (published online 10 April 2015). 
F was written more than a century before R; hence, there must have been a codex containing a text of the same tradition as $\mathrm{R}$ written before the eleventh century. Similarly, $\gamma$ (which otherwise is a member of the $\alpha$ family) written no later than the twelfth century was influenced by $\varphi$. Do note that $\mathrm{G}$ is extant only for the Asclepius and the De deo Socratis and A for the De deo Socratis and part of the De Platone.

Socr. prol. 4 p. 110 in hoc edd.] id hoc B $\delta$ id RA

Socr. 3 p. 124 dei $\mathrm{B}^{2} \mathrm{RG}$ ] diei $\mathrm{B} \delta$

Socr. 3 p. 125 ita omnibus] in omnibus $\mathrm{R} \gamma$

Socr. 4 p. 128 ceteri $\left.\mathrm{B}^{2} \mathrm{R} \gamma\right]$ celeri $\mathrm{B}$

Socr. 8 p. 140

Socr. 16 p. 155

Plat. 1.2 p. 184

Ascl. 5

Ascl. 36 enim semper] semper enim $\mathrm{R} \gamma$ possident $\mathrm{B}^{2} \mathrm{R} \gamma$ ] possideant $\mathrm{B} \delta$ se utilem $R A$ ] sentilem $B \delta$ defluentes $\mathrm{RGT}^{2}$ ] defluens $\mathrm{B} \delta$ nutricat] nutria RG

$\varphi$ also probably influenced the text of $\mathrm{C}$ and $\mathrm{H}$ as well, but since both of those are not sincere witnesses to the tradition, but learned recensions, there is no need to tarry on them here. Suffice it to say, that the existence of $\varphi$-readings in the main tradition before $\mathrm{R}$ was copied demonstrates that there existed a manuscript of the same tradition as $\mathrm{R}$ more than two centuries before $\mathrm{R}$ itself was copied.

\section{$3.2 F, \varphi$ and $\omega$}

There is, however, another way to account for the place of $F$ in the manuscript tradition. First we need to establish with absolute clarity that $\mathrm{F}$ is a $\delta$ manuscript.

Socr. 7 p. 136

Ascl. 6

Ascl. 11

Ascl. 14

Plat. 1.5 p. 190

Plat. 1.12 p. 206

Plat. 1.14 p. 209

Plat. 1.16 p. 214

Plat. 1.17 p. 216

Plat. 2.3 p. 224

Plat. 2.24 p. 260 navio] navi $\mathrm{B}$ (corr. $\left.\mathrm{B}^{2}\right)$ om. $\mathrm{F} \delta$ non aquae $\left.\mathrm{B} \mu \mathrm{GF}^{2} \mathrm{R}\right]$ non aeque $\mathrm{V}$ namque $\mathrm{F} \delta$ munita sunt $B$ ] munita sint $\mu \mathrm{G}$ munita sunt enim (munitast enim L) FR $\delta$ pura $\mathrm{F} \delta$ ] piua $\mathrm{R}$ om. $\mathrm{B}$ quia nata $e d d$.] quando nata RK quanta $\mathrm{B} \mu \mathrm{NPU}$, quando FGLT genitor $\mathrm{B}$ ] rerumque genitor $\mathrm{AF} \delta$ rerum genitor $\mathrm{R}$ et fortunae $\mathrm{B} \mu \mathrm{AR}$ ] eius fortunae $\mathrm{F} \delta$ bifori via $\mathrm{B} \mu \mathrm{A}$ ] biforidia $\mathrm{F} \delta$, symphonia $\mathrm{R}$ Rom. femina $B \mu R$ ] semina (semen ita N) F $\delta$ simul $\mathrm{CPa}$ ] simił $\mathrm{R}$ simulabo $\mathrm{B} \mu$ simul ob $\mathrm{F} \delta$ commodum $\left.\mathrm{B}^{2} \mathrm{FNLU}\right]$ quomodo $\mu \mathrm{R}$, commodo $\mathrm{BP}$ suboles $\mathrm{F} \delta$ ] subleves $\mathrm{B} \mu \mathrm{R}$ 
Plat. 2.15 p. 241 neccessarias cupidine sunt $\mathrm{B} \mu$ necessaria cupidine sunt $\mathrm{F} \delta$ necessarias cupidines acuunt $\mathrm{R}$ talem $\mathrm{B} \mu \mathrm{R}$ ] palam $\mathrm{F} \delta$

Plat. 2.11 p. $236 \quad$ si quis $\left.\mathrm{B}^{2} \mu\right]$ si qui $\mathrm{BR}$ sequi $\delta$ sequi ut $\mathrm{F}$

Plat. 2.12 p. 238 aspernetur $\mu$ ] spernetur $\mathrm{BR}$, aspernatur $\mathrm{F} \delta$

Plat. 2.14 p. 239 potiantur $\mathrm{B}^{2} \mathrm{~F} \delta$ ] potiatur $\mathrm{B} \mu$ ponantur $\mathrm{R}$

Plat. 2.26 p. 260 sed ut magistratus con. Sinko] nec ita sexus esse tus $\mathrm{B}$ nec ita sexus esse onestus $\mathrm{M}$ nec ita sexus esse $\mathrm{V}$ nec ita sexus esse stratus FR $\delta$

mund. 6 p. $301 \quad$ propontis $\mathrm{H}$ ] propontius $\mathrm{F} \delta$ propintus $\mathrm{B}$ propontus $\mathrm{R}$ faucis $\mathrm{B} \mu$ ] fauces $\mathrm{FR} \delta$

ultraque $\mathrm{BMR}$ ] utraque $\mathrm{VF} \delta$

mund. 9 p. 307 gravidatur $\mathrm{B} \mu \mathrm{R}$ ] gravidat $\mathrm{F} \delta$

mund. 14 p. 320 sinu id est $F \delta$ ] sin ides $B V$, sui id est $R$

mund. 15 p. 321

mund. 15 p. 322

mund. 16 p. 323 se dat FNPL $\left.{ }^{2} \mathrm{U}\right]$ se dant $\mathrm{L}$ sed $\mathrm{BR}$ se $\mathrm{V}$ claricantes F $\delta$ ] claria cantes BVR

mund. 21 p. 337

mund. 26 p. 348 humanis edd.] sumeris BVR meris $\mathrm{F} \delta$ humeris $\mathrm{B}^{2}$ deferre BVR] differre $\mathrm{F} \delta$

mund. 29 p. 354 divisa $\mathrm{BR}$ ] diversa $\mathrm{F} \delta$ simplici circumactu BR] simpliciter cum actu F $\delta$

On the strength of both so many conjunctions on less significant readings, and on a few shared Bindefehler (talem/palam; bifori via/biforidia; suboles/subleves), it cannot be doubted that $\mathrm{F}$ was copied from $\delta$, as indeed has been the consensus for a century or more. Nonetheless, as I have shown above, $\mathrm{F}$ shares significant readings with $\mathrm{R}$, which indicates that it must have had access to another branch of the manuscript tradition. It also shares important readings with $\mathrm{B}$ :

Socr. prol. 1 p. 104 cognostis $\mathrm{BF}$ ] recognoscitis $\mathrm{R}$, cognoscitis $\delta$

Socr. prol. 4 p. 109 pinnis $\mathrm{B}^{2}$ ] pennis $\mathrm{B} \mathrm{AGFP}^{2}$ om. $\delta$ alis $\mathrm{R}$ alis utrimque $\mathrm{O}$

Socr. 20 p. 166 ea B $\mu \mathrm{AGF}]$ om. RO $\delta$

Ascl. 3 torrenti $\mathrm{B} \mu \mathrm{F}$ ] torrentis $\mathrm{R} \gamma \delta$

Ascl. 14 nata non $\mathrm{B} \mu \mathrm{F}$ ] nata $\mathrm{R} \gamma \delta$

Plat. 1.11 p. $203 \quad$ inerrabili $\mathrm{B} \mu \mathrm{F}]$ inenarrabili $\mathrm{R} \gamma \delta$

Plat. 1.14 p. $210 \quad$ eos $\delta]$ eo $\mathrm{B} \mu \mathrm{F}$ et $\mathrm{R} \gamma$

Plat. 2.24 p. 255 alii BMF] om. $\delta$ (R deest)

It also contains non- $\delta$ readings with BR:

Ascl. 11

ea demum $B F R \gamma]$ eadem vero $\delta$ meum BFR] eum $\delta \gamma$ 
Ascl. 22

Ascl. 23

Plat. 1.6 p. 193

Plat. 1.12 p. 205

Plat. 2.22 p. 251

mund. 17 p. 328

mund. 18 p. 329

mund. 22 p. 238 lege $\mathrm{BFR} \gamma$ ] longe $\delta$

semper BFR] om. $\delta \gamma$

sensibus BFR $\gamma$ ] sensus $\delta$

cogitationes BFR $\gamma$ ] cognitiones $\delta$

praesto BFR] profecto $\delta$

cognitum est vim edd.] cognita est vis $\mathrm{CH}$ cognitu

est vis BFR cognitus est vis $\delta$

spiritus BFR] spiritu $\delta$

vicibus $\mathrm{BFR}$ ] vicinibus $\delta$

One way to make sense of these counterindications is to posit radical contamination: that is, while copied from $\delta$, it was contaminated by both of the other two branches of the manuscript tradition. But the contamination could not have come from just any $\alpha$ manuscript: the occasional agreement with $\mathrm{B}$ against $\gamma$ and $\mu$ suggests that $\mathrm{F}$ must have been contaminated by $\mathrm{B}$ itself, if not some unknown gemellus.

But these facts are open to another interpretation. Above, in passage 2.1a, I glossed over F's reading. As I argued there, this passage clearly points to a line in the archetype which read scribam nomine which was infelicitously corrected to scribo nomini by means of a bo and $n i$ inserted supralinearly. F reads scribo nomini, and in fact is the only complete witness to the corrected text apart from the factitious boni of $\delta$. One could no doubt come up with all sorts of theories to explain this: the simplest solution, however, is that $\mathrm{F}$ was contaminated by the archetype itself.

Another passage offers a hint in favour of this interpretation:

Socr. prol. 4 p. 110 alis persequax oculis perspicax unguibus pertinax $\mathrm{B}$ edd.] ales (om. $\mathrm{N}$ ) oculis perspicax unguibus pertinax $\mathrm{R} \delta$ ales oculis persequax unguibus pertinax $\mathrm{F}$

There can be no doubt B offers the correct reading, a quintessentially Apuleian tricolon, and it cannot possibly have come about by scribal conjecture. Yet the conjunction of $\mathrm{R} \delta$ suggests that the archetype indeed read ales oculis perspicax, and so we must be dealing with another corrected passage, where persequax was inserted above the line:

\section{i persequax alesoculisperspicax}

The fact that $\mathrm{F}$ alone contains persequax with $\mathrm{B}$ cannot be a coincidence, but the fact that it contains it in the wrong position and in place of another authentic word proves that $\mathrm{F}$ cannot have gotten persequax from B. Instead, it can only suggest that $\mathrm{F}$ (or its unknown, hy pothetical parent) got the word 
directly from archety pe, misinterpreting the $i$ persequax as a replacement for perspicax (as if [ve]l persequax or even $i[d$ est] persequax), not an addition.

\subsection{The geography of a manuscript tradition}

The complexity of the manuscript tradition, as I have sketched it above, can become much clearer when discussed in terms of the actual geographical circulation of manuscripts. ${ }^{15}$ After the Apuleian corpus was split into two halves - the Apology, the Florida, and the Met. finding a relatively undisturbed haven in Montecassino, the philosophica migrating to the fertile ground of Northern Europe - the story of our half begins in the heartland of the Carolingian Renaissance. There B was copied from the archetype, probably in the ninth century for the court library of Louis the Pious. It next turns up in the possession of Nicholas of Cusa in the fifteenth century. During that time, it acquired some paratextual elements, notes on the first folio and a little recipe for the treatment of epilepsy after the explicit. I have not been able to find other examples of this recipe. Nonetheless, we can assume in the absence of other evidence that the manuscript did not travel far in the Middle Ages. Many of Nicholas' important manuscript discoveries took place in Cologne, and the distance between Aachen and Cologne is not more than forty miles. In all likelihood, B may have been taken to Cologne by the next century, and remained there until the fifteenth century. At any rate, there is no evidence it was anywhere else; no trace of it is found at Lorsch, where many of the palace manuscripts ended up.

Similarly, one can say little with confidence about the origin of $\varphi . R$ was copied in the mid-thirteenth century in Amiens; its archetype may have been local, although some pieces in Fournival's collections seem to have had a connection with Orléans. Obviously, it was copied from the archetype; if we knew where the archetype was located we would be in a better position. Here F can be of some assistance: besides the philosophica, it also contains an important witness to the ten-book tradition of Pliny's Letters. That tradition stems from a partially extant archetype (New York, Morgan Library, MS M.462), which was at Meaux and then at Paris in the later Middle Ages. It produced two offspring: $\mathrm{F}$ and Florence, Bibliotheca laurenziana, Ashburnham 98, which was written in the ninth century and at some point later was at Beauvais, forty miles south of Amiens. The fact that the two manuscripts to which $\mathrm{F}$ seems to be more or less distantly related can both be placed within so narrow a zone, strongly suggests that $\varphi$ was a local product, copied from $\omega$ perhaps not far from Amiens. Tantalizingly, the abbey of Corbie is just ten miles east of Amiens, a fact which led Klibansky

${ }^{15}$ My discussion here is deeply indebted to Klibansky/Regen; for each manuscript listed above, I have already indicated its number in their catalog. 
to suggest that $\varphi$ was housed there. ${ }^{16}$ There is no conclusive paleographical evidence which points to Corbie ${ }^{17}$ and so in the absence of other evidence, all I will suggest is that $\varphi$ was somewhere near Amiens.

$\delta$ was also in Northern France. There is no evidence to fix where the earliest copy, $\mathrm{N}$, was made. But soon after $\mathrm{N}$ was written, its sibling $\mathrm{P}$ was copied in the late eleventh or early twelfth century. Current scholarship puts the place of its writing in France; the fact that it ended up in the library of the Victorines in Paris supports this supposition. The fragment preceding the incipit of the Socr. can give us an additional clue:

... a lascivis totius delicti exclusa, quod praepotentis nobis non deneget misericordia. Cuius nutu et bonitate consistent atque sanctificantur omnia quae in caelo manent et quae in terra. Amen (f. 2 r [3r]).

This text does not seem to be in print; nonetheless, a full copy of it seems to be found in a tenth-century miscellaneous manuscript, BAV Reg. lat. 300, 78r. It is a sermon in honor of St. Stephen, and based on the 'Kristeller Rule' (the provenance of a manuscript is likely to be the provenance of its rarest text), it is thought to have been written at St. Stephen's in Sens or Auxerre, separated by a distance of about fifty miles. ${ }^{18}$ In the absence of other evidence, our manuscript should be placed there too.

As is the case in other textual traditions, the extensive contamination which makes editing the text so difficult is due precisely to its popularity in twelfth-century France. Undoubtedly the cause is the Platonic revival of the period, which saw a dramatic rise in the fortunes of several classical and late ancient texts which gave medieval readers access to Plato's doctrines: Calcidius, Macrobius, and Boethius, among others. ${ }^{19}$ Apuleius never quite gained a comparable circulation, but nonetheless, the diffusion of copies of his works reflects that of theirs on a smaller scale. In this context, the prevalence of contamination makes sense: it was a scholarly revival in Apuleius' fortunes, and such an audience would have taken an activist role in shaping the texts at their disposal. Fortunately for them, and unfortunately for editors, they had access to three different textual traditions in a relatively small part of Northern France. This also explains partially why $\varphi$ had little impact on the main tradition of the corpus despite its excellence: it was

${ }^{16}$ R. Klibansky, The Continuity of the Platonic Tradition, Millwood, NY 1982 (=1939²): 6-7, as well as Klibansky/Regen, no. 90.

${ }_{17}$ One could adduce R's bizarre reading at Socr. 2 p. 121 ennio] cainio R. Corbie abminuscule offers one example of a script where en could be read as $c a$ (see, for example, the plate at $C L A$ V.661), but this is mere innuendo.

${ }^{18}$ Guy Lobrichon, "Moines et clercs à Sens et Auxerre au xe siècle: Culture et société," MLatJb 24/25, 1989-90, 277-94 at 293.

${ }^{19}$ See J. Stover, Reading Plato in the Twelfth Century, PhD Diss., Harvard 2011. 
lodged in territory already occupied by $\delta$ 's descendants, and many of its best readings had already in the late eleventh century or earlier been skimmed off from the archetype by $\mathrm{F}$ or its parent.

\subsection{Editing Apuleius}

Much more could be said and needs to be said on the topic of the tradition of the philosophica. As a conclusion, let me suggest some possible paths forward. Contamination is far more rampant than previous editors have acknowledged (the 'Hankins Rule' - where contamination can happen, it will happen), and the admittedly appalling state of the paradosis offers no fig leaf to cover editorial imprecision. $\mathrm{F}$ is important as an independent witness to the archetype, but must be used with caution. $\mathrm{C}$ and $\mathrm{H}$ are hypercontaminated and actively edited scholarly texts; they should only be used as a storehouse of (sometimes excellent) medieval conjectures. But the whole $\alpha$ tradition, excluding obviously $\mathrm{B}$, is also contaminated, $\mathrm{M}$ and $\mathrm{V}$ from $\delta$, $A$ and $G$ from $\varphi$. In fact, it is worth examining whether it is time to dust off Thomas's old theory that B itself is the source of the whole $\alpha$ tradition, and send $\mathrm{M}, \mathrm{V}, \mathrm{A}$, and $\mathrm{G}$ off to honourable retirement. Contamination from $\varphi$ is perhaps sufficient to explain the good readings in the other $\alpha$ manuscripts. The unlikely theory of Klibansky and Regen that the late manuscripts related to $\mathrm{R}$ - which share many of its readings discussed above - are not copies of it, but rather of its archety pe, also needs to be more seriously explored. ${ }^{20}$ The editio princeps of Bussi (Rome 1469) also deserves further consideration, particularly in regard to its likely relationship with R. Bussi, in fact, may well have seen $\mathrm{R}$ itself when he was a student at Paris, before entering the service of Nicholas of Cusa. ${ }^{21}$

Here I propose as a working hypothesis that the text of Apuleius perhaps may be constructed on the basis of a tripartite stemma of $B, R$, and $\delta$, while taking into account the demonstrable fact that the archetype was corrected and that therefore a strict principle of two against one does not work in all cases. What follows is a simplified editorial stemma, to replace that of Reynolds in Texts and Transmission, which indicates, I believe, a suitably robust base of manuscript evidence to accurately reconstruct the paradosis:

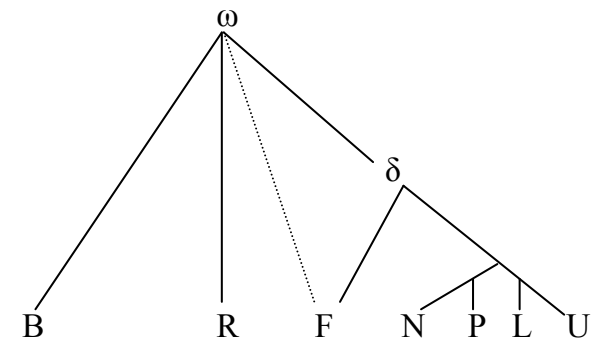

${ }^{20}$ Klibansky/Regen 158-168.

${ }^{21}$ See Arfé, "The Annotations," 171 and Stover, A New Work, chapter 1.4. 
Unfortunately, Regen's published work does not allow us to divine what stemmatic basis he was producing his edition on. Nonetheless, the reconstruction presented here accords with the appendix to his and Klibansky's manuscript catalogue, presented I hope in a more accessible way and on a firmer textual basis. 